\title{
MODEL PERKULIAHAN BERBASIS FORTOFOLIO DALAM MENGEMBANGKAN PEMAHAMAN MAHASISWA DALAM PENGEMBANGAN MEDIA PEMBELAJARAN PAUD
}

\author{
Reni Nurapriani \\ E-mail: reni.nurapriani@fkip-uninus.ac.id \\ Universitas Islam Nusantara, Bandung, Indonesia \\ Agus Ruswandi \\ E-mail: agus.ruswandi@fkip-uninus.ac.id \\ Universitas Islam Nusantara, Bandung, Indonesia \\ Riki Ruswandi \\ E-mail:riki.ruswandi@fkip-uninus.ac.id \\ Universitas Islam Nusantara, Bandung, Indonesia
}

Article received: 28 Oktober 2019, Review process: 09 Desember 2019

Article published: 30 Maret 2020

\begin{abstract}
For managing learning and teaching there needs to be a suitable strategy to be able to organize learning so that it becomes better. One of the strategies that must be used by kindergarten teachers is the strategy in developing learning media. Learning media should be educational, economical, practical and contextual. To support this problem, the lecture who teach "Strategi Pembelajaran PAUD", with based on fortfolio learning model. The purpose this research to develop students' abilities in developing media available in schools so that it becomes an educational medium of learning value. The method used in this research is quasy experiment with one group pre test posttest design model with independent $t$ test. The results of this study indicate that the learning based on portfolio model can improve student understanding in terms of development strategies for kindergarten learning media with an average pretest of 54.00 and posttest increasing to 84.33. Based on the t test through SPSS it was concluded that there was a significant influence on the use of fortfolio-based learning on student understanding in developing learning media
\end{abstract}

Keyword: learning, media, fortofolio model.

\begin{abstract}
Abstrak
Dalam mengelola pembelajaran perlu adanya strategi yang cocok untuk dapat mengatur pembelajaran agar menjadi lebih baik. Salah satu strategi yang harus dikuasai oleh guru PAUD adalah strategi dalam pengembangan media pembelajaran. Media pembelajaran
\end{abstract}


hendaknya bersifat edukatif, ekonomis, praktis dan kontekstual. Untuk mendukung masalah tersebut, maka dalam perkuliahan mata kuliah strategi pembelajaran PAUD dilakukan kegiatan perkuliahan dengan perkuliahan berbasis fortofolio. Penelitian ini bertujuan untuk mengembangkan kemampuan mahasiswa dalam mengembangkan media yang tersedia di sekolah sehingga menjadi media yang bernilai edukatif dalam pembelajaran. Metode yang digunakan dalam penelitian ini adalah quasy eksperimen dengan model one group pre test posttest design dengan independent $t$ test. Hasil penelitian ini menunjukkan bahwa model perkuliahan berbasis fortofolio dapat meningkatkan pemahaman siswa dalam hal strategi pengembangan media pembelajaran PAUD dengan rata-rata pretest sebear 54,00 dan postest meningkat menjadi 84,33. Berdasarkan uji t melalui SPSS disimpulkan bahwa ada pengaruh yang signifikan penggunaan pembelajaran berbasis fortofolio terhadap pemahaman mahasiswa dalam mengembangkan media pembelajaran.

Kata Kunci: media, pembelajaran, model fortofolio

\section{PENDAHULUAN}

Penelitian didasari pada hasil kegiatan Penugasan Dosen di Sekolah (PDS) oleh Kemenristekdikti yang dilaksanakan pada tahun 2018. Salah satu kesimpulan dari kegiatan tersebut adalah perlunya kemampuan guru dalam mengembangkan strategi pembelajaran diantaranya dalam pengembangan media pembelajaran yang edukatif, praktis serta ekonomis (Nurapriani et al., 2018). Pada tahun 2019, Dosen yang ditugaskan kembali untuk mengikuti kegiatan yang sejenis dituntut untuk menerapkan atau menyampaikan apa yang diperoleh di sekolah yang kemudian disampaikan kembali kepada mahasiswa di kelas perkuliahan. Fokus dari kegiatan tersebut adalah untuk memberikan penguatan pada mahasiswa dalam hal pengembangan media pembelajaran yang edukatif, praktis dan ekonomis.

Seperti yang ditemukan dari observasi di TK Mekar Arum pada tahun 2018, guru TK di sekolah itu hanya memanfaatkan lingkungan dan dijadikan sumber belajar hanya dua sampai tiga kali dalam satu semester. Artinya Guru lebih dominan menyampaikan pelajaran di dalam kelas saja padahal materi yang disajikan berhubungan dengan lingkungan sekolahnya. Untuk mengatasi hal itu perlu adanya diskusi kelompok diantara para guru kelas dalam bentuk diskusi mingguan untuk mendiskusikan masalah pemanfaatan lingkungan sekolah sebagai media belajar. Dalam kegiatan diskusi, guru dapat share pengalaman dalam memanfaatkan lingkungan sekitar sekolah sebagai media belajar untuk mencapai hasil belajar yang optimal. 
Bagi guru yang sudah sangat berpengalaman memungkinkan akan menjadi lebih mudah, dan bagi guru yang pengalamannya belum banyak akan menambah pengetahuan. Keunggulan diskusi mingguan adalah keterlibatan guru bersifat holistik dan komprehensip dalam semua kegiatan. Dari aspek lainnya guru dapat saling tukar pendapat, saling memberi saran, tanggapan dan beribincang-bincang dengan rekan sejawat sebagai peluang bagi mereka untuk meningkatkan kemampuan dan pengalaman.

Dalam kegiatan belajar mengajar yang berlangsung, akan terbentuk interaksi yang memiliki manfaat. Guru dan peserta didik yang menggerakannya. Interaksi guru dan peserta didik ini tercipta karena guru mampu menciptakan lingkungan sekolahnya yang memiliki nilai edukatif. Guru harus mampu memberikan pelayanan yang memadai bagi peserta didik, dengan menyediakan lingkungan yang menyenangkan dan membuat anak termotivasi untuk belajar. Guru harus bisa menjadi pembimbing yang baik dengan bijaksana dan adil, sehingga tercipta hubungan yang harmonis antara guru dengan peserta didik.

Kualitas suatu kegiatan pembelajaran diantaranya ditentukan oleh kualutas interaksi komponen-komponen dalam sistem pembelajaran. "Komponen tersebut meliputi tujuan, bahan ajar (materi), anak didik, sarana, media, metode, partisipasi masyarakat, performance sekolah, dan evaluasi pembelajaran" (Shochib, 1998). Keadaan lingkungan sekolah, dan evaluasi pembelajaran serta memaksimalkan keduanya merupakan faktor yang ikut menentukan kualitas pembelajaran di sekolah.

Untuk mencapai proses pembelajaran yang maksima, maka perlu adanya kegiatan interaksi dua arah yang aktif dan efektif belajar mengajar terutama yang terjadi di kelas. Dengan demikian, kegiatannya adalah bagaimana menjadikan terjadinya hubungan antara guru dan bahan ajar yang dibuat dan dengan peserta didik. Interaksi ini merupakan proses komunikasi penyampaian pesan pembelajaran agar bisa maksimal. Hal ini sejalan dengan yang dikemukakan Arief S Sadiman yang mengatakan bahwasannya "proses belajar mengajar pada hakikatnya adalah proses interaksi yaitu proses penyampaian pesan melalui saluran media, teknik, serta metode ke penerima pesan yaitu peserta didik" (Sadiman, 1996).

Berhasilnya tujuan pembelajaran ditentukan oleh banyak faktor diantaranya adalah faktor guru dalam memilih media pembelajaran. Media memegang peranan penting dalam 
pembelajaran, walaupun pada intinya media bukan merupakan satu-satunya faktor yang mendukung tercapainya tujuan pembelajaran. Banyak manfaat yang dapat diambil dari pemanfaatan media dalam pembelajaran diantaranya adalah pemanfaatan media pembelajaran dapat memperjelas, merinci dan mendeskripsikan penyajian pelajaran agar tidak terlalu verbalistik dan tidak terlalu umum. Dengan menggunakan media pembelajaran tepat variatif dapat mengatasi keadaan peserta didik yang kurang aktif dalam belajar. Dengan demikian, sesuai dengan pendapatnya Piran media pembelajaran dapat bermanfaat untuk; “(1) menimbulkan motivasi dan gairah belajar, (2) memungkinkan interaksi yang lebih langsung antara siswa dengan lingkungan dan kenyataan, dan (3) memungkinkan peserta didik belajar sendiri menurut kemampuan dan minatnya" (Piran, Wiroatmodjo, 2002).

Berdasarkan hal tersebut, maka penulis dalam konteks kegiatan PDS di tahun 2019 mengkaji mengenai pengembangan media pembelajaran di PAUD dengan model pembelajaran berbasis fortofolio. Kaitannya dengan program pembelajaran di kelas, portofolio dapat diartikan sebagai suatu berkas karya yang disusun berdasarkan sistematika tertentu, sebagai bukti penguasaan atas tujuan belajar (BSNP, 2017). Lebih lanjut, Budimansyah (2002:1) dalam Purba (Purba, 2006) menjelaskan bahwa :

"....Portofolio dapat diartikan sebagai suatu wujud benda fisik, sebagai suatu proses sosial pedagogis, maupun sebagai adjective. Sebagai suatu wujud benda fisik portofolio adalah bundel, yakni kumpulan atau dokomentasi hasil pekerjaan peserta didik yang disimpan dalam suatu bundle". "Contoh portofolio tentang hasil tes awal (pre-test), tugas-tugas, catatan anekdot, piagam penghargaan, keterangan melaksanakan tugas tersruktur, hasil tes akhir (post-test) dan sebagainya". "Sebagai suatu proses sosial pedagogis, portofolio adalah collection of learning experience yang terdapat didalam pikiran peserta didik baik yang berwujud pengetahuan (kognitif), keterampilan (skill), maupun nilai dan sikap (afektif). Adapun sebagai suatu adjective portofolio sering disandingkan dengan konsep lain, misalnya dengan konsep pembelajaran dan penilaian".

Hal senada juga diungkapkan oleh Trianto (Trianto, 2010), menurutnya portofolio dapat diartikan sebagai kumpulan hasil karya (artifact) yang dimiliki siswa (baik yang berbentuk tertulis, maupaun berbagai penampilan yang tersimapan dengan rapi), yang menggambarkan perkembangan belajar ataupun menunjukan prestasi terbaik yang dihasilkan 
peserta didik di dalam kelas ataupun di luar kelas selama mengikuti program pembelajaran, berdasarkan indikator dan kriteria yang ditetapkan.

Portofolio dalam program pembelajaran dapat digunakan untuk mengetahui perkembangan belajar siswa. Popham dalam Purba (Purba, 2006) menjelaskan bahwa portofolio adalah metode pengumpulan informasi atau data secara sistematik atas hasil pekerjaan seseorang sepanjang waktu yang membantu siswa dan guru menilai pertumbuhan dan perkembangan siswa. Hal ini dipertegas oleh Cotes dalam Purba (Purba, 2006) yang mengemukakan bahwa portofolio dapat melacak perkembangan kemampuan siswa karena membuka saluran diskusi di antara guru dan siswa. Untuk lebih jelasnya, pemerintah menjelaskan bahwa :

"bagi guru, portofolio menyajikan wawasan tentang banyak segi perkembangan siswa dalam belajarnya, cara berfikirnya, pemahamannya atas pelajaran yang bersangkutan, sikapnya terhadap mata pelajaran yang bersangkutan, dan sebagainya (Depdiknas, 2004)."

Dari uraian di atas dapat disimpulkan bahwa portofolio berkaitan dengan kegiatan pembelajaran merupakan hasil karya yang dimiliki peserta didik yang mampu menggambarkan perkembangan belajar peserta didik selama mengikuti program pembelajaran. Hanya saja perbedaannya, dalam konteks artikel ini adalah yang menjadi peserta didik adalah mahasiswa dan sebagian dari mahasiswa sudah memiliki pengalaman mengajar di PAUD atau lembaga sejenis.

\section{METODOLOGI}

Pendekatan yang digunakan dalam penelitian ini adalah dengan pendekatan kuantitatif. Sedangkan metode penelitian yang digunakan adalah metode penelitian quasy eksperimen. Penelitian eksperimen adalah metode penelitian yang digunakan untuk mencari pengaruh perlakuan tertentu terhadap yang lain dalam kondisi yang terkendali (Sugiyono, 2011). Dari pendapat tersebut dapat diambil kesimpulan bahwa penelitian eksperimen merupakan jenis penelitian dengan melakukan percobaan terhadap kelompok eksperimen, kepada tiap kelompok eksperimen dikenakan perlakuan-perlakuan tertentu dengan kondisikondisi yang dapat di kontrol dan diketahui aktivitas perubahannya. 
Desain yang dipakai dalam penelitian ini adalah Pretest-and Post-test One Group Design dengan pola: $\mathrm{O}_{1} \mathrm{X}_{2}$ dimana sekelompok subjek diambil dari populasi tertentu dan dilakukan pretest kemudian dikenai treatment secara berturut-turut. Setelah diberikan treatment, subjek tersebut diberikan posttest untuk mengukur hasil belajar padal kelompok tersebut. Evaluasi yang diberikan mengandung bobot yang sama. Perbedaan antara hasil pretest dengan posttest tersebut menunjukkan hasil dari perlakuan yang telah diberikan (Suharsimi, 2006).

Adapun desai penelitian yang digunakan dalam penelitian ini penulis ganbarkan pada gambar berikut ini:

\section{$\mathrm{O}_{1} \mathrm{X} \mathrm{O}_{2}$}

Keterangan:

$\mathrm{O}_{1} \quad=$ Nilai Pretest (Sebelum Berbasis Fortofolio)

$\mathrm{X}=$ Perlakuan yang diberikan

$\mathrm{O}_{2} \quad=$ Nilai Postest (Setelah Berbasis Fortofolio)

Subjek penelitian ini adalah mahasiswa semester V Program Studi PG PAUD FKIP Universitas Islam Nusantara Bandung yang berjumlah 30 mahasiswa. Langkah-langkah analisis data kuantitatif melalui uji normalitas data, menguji hipotesis dengan uji t independent sample t test dengan menggunakan SPSS. Kemudian melakukan penafsiran hasil analisis data kuantitatif tersebut. Dengan jenis penelian kuasi eksperimen menggunakan Pretest- and Post-test One Group Design ini, peneliti melakukan pretest pada awal pertemuan untuk mengetahui pemahaman mahasiswa dalam pengembangan media pembelajaran. Setelah itu barulah dilakukan pos-test untuk mengetahui hasil akhir dari treatment/ perlakuan yang sudah diberikan pada mahasiswa.

\section{HASIL DAN PEMBAHASAN}

\section{Pre Test Pemahaman Mahasiswa dalam Strategi Pengembangan Media Pembelajaran}

Sebelum perkuliahan dimulai, mahasiswa terlebih dahulu mengisi lembar jawaban pretes dengan model soal studi kasus dalam hal strategi pengembangan media pembelajaran 
AWLADY: Jurnal Pendidikan Anak

Homepage: www.syekhnurjati.ac.id/jurnal/index.php/awlady

Email : pgrasyekhnurjati@gmail.com

P-ISSN: 2541-4658

E-ISSN: 2528-7427

dengan tema tertentu untuk pembelajaran PAUD baik di kelas A maupun kelas B. Aspek yang menjadi kajian pembelajaran paud adalah mengenai membaca dan mengenal huruf. Adapun bentuk tesnya adalah tes tertulis dengan studi kasus tersebut. Mahasiswa diminta membuat uraian tentang strategi pengembangan media pembelajaran dengan indikator penilaian (1) Kesesuaian Media Pembelajaran dengan Tujuan Pembelajaran (2) Unsur edukasi dalam Media Pembelajaran, (3) Langkah-langkah (petunjuk) dalam penggunaan media pembelajaran, dan (4) Media Pembelajaran Bernilai praktis, ekonomis dan kontekstual.

Untuk mengetahui pemahaman mahasiswa dalam mengembangkan media pembelajaran penulis berhasil merekapitulsi nilai pretest sebagai berikut:

\section{Tabel 1}

Nilai Pretest Mahasiswa

\begin{tabular}{c|c|c|c|c|c}
\hline \multirow{2}{*}{$\begin{array}{c}\text { Kode } \\
\text { Mahasiswa }\end{array}$} & \multicolumn{4}{|c|}{ Indikator Penilaian } & \multirow{2}{*}{ NILAI AKHIR } \\
\cline { 2 - 5 } S 1 & 15 & 10 & 10 & 10 & 45 \\
\hline S 2 & 10 & 10 & 10 & 10 & 40 \\
\hline S 3 & 20 & 15 & 10 & 10 & 55 \\
\hline S 4 & 10 & 10 & 10 & 5 & 35 \\
\hline S 5 & 15 & 15 & 20 & 15 & 65 \\
\hline S 6 & 15 & 15 & 15 & 15 & 60 \\
\hline S 7 & 15 & 15 & 10 & 10 & 50 \\
\hline S 8 & 10 & 10 & 10 & 5 & 35 \\
\hline S 9 & 10 & 15 & 15 & 10 & 50 \\
\hline S 10 & 15 & 15 & 10 & 15 & 55 \\
\hline S 11 & 15 & 15 & 20 & 10 & 60 \\
\hline S 12 & 15 & 15 & 15 & 10 & 55 \\
\hline S 13 & 15 & 15 & 20 & 15 & 65 \\
\hline S 14 & 10 & 10 & 25 & 10 & 55 \\
\hline S 15 & 20 & 20 & 15 & 10 & 65 \\
\hline S 16 & 15 & 15 & 10 & 10 & 50 \\
\hline S 17 & 20 & 20 & 20 & 10 & 70 \\
\hline S 18 & 25 & 15 & 10 & 15 & 65 \\
\hline S 19 & 15 & 15 & 15 & 10 & 55 \\
\hline S 20 & 10 & 10 & 10 & 10 & 40 \\
\hline S 15 & & & & \\
\hline & & 15 & 35 \\
\hline
\end{tabular}


AWLADY: Jurnal Pendidikan Anak

Vol. 6, No. 1, Maret 2020

Homepage: www.syekhnurjati.ac.id/jurnal/index.php/awlady

Email : pgrasyekhnurjati@gmail.com

P-ISSN: 2541-4658

E-ISSN: 2528-7427

\begin{tabular}{c|c|c|r|r|c}
\hline \multirow{2}{*}{$\begin{array}{c}\text { Kode } \\
\text { Mahasiswa }\end{array}$} & \multicolumn{4}{|c|}{ Indikator Penilaian } & \multirow{2}{*}{ NILAI AKHIR } \\
\cline { 2 - 5 } S 21 & 15 & 2 & 3 & 4 & 60 \\
\hline S 22 & 20 & 20 & 20 & 10 & 70 \\
\hline S 23 & 10 & 15 & 15 & 10 & 50 \\
\hline S 24 & 10 & 10 & 15 & 10 & 45 \\
\hline S 25 & 20 & 25 & 10 & 5 & 60 \\
\hline S 26 & 10 & 20 & 20 & 10 & 60 \\
\hline S 27 & 10 & 10 & 15 & 10 & 45 \\
\hline S 28 & 10 & 15 & 15 & 15 & 55 \\
\hline S 29 & 15 & 15 & 10 & 20 & 60 \\
\hline S 30 & 10 & 10 & 10 & 15 & 45 \\
\hline RATA-RATA & & & & & $\mathbf{5 4}$ \\
\hline
\end{tabular}

Indikator :

$1=$ Kesesuaian Media Pembelajaran dengan Tujuan Pembelajaran

2 = Unsur edukasi dalam Media Pembelajaran

3 = Langkah-langkah (petunjuk) dalam penggunaan media pembelajaran

4 = Media Pembelajaran Bernilai praktis, ekonomis dan kontekstual

Berdasarkan deskripsi di atas, dapat disimpulkan bahwa kemampuan dan pemahaman mahasiswa dalam menggunakan dan mengembangkan media pembelajaran di PAUD sangat rendah terbukti dengan skor rata-rata hanya 54 dari skor maksimal 100. Dari empat indikator penilaian yang dilakukan terhadap mahasiswa dapat diketahui bahwa kemampuan mahasisw yang paling rendah adalah dalam membuat media pembelajaran yang bernilai praktis, ekonomis dan kontekstual. Pada umumnya mahasiswa hanya menggunakan media pembelajaran yang tersedia di sekolah saja tanpa memperhatikan konteks media dengan materi yang diajarkan.

Hal tersebut sejalan dengan hasil penelitian yang dilakukan Jazariyah pada tahun 2019 yang hasil penelitiaannya menyebutkan bahwa media yang ditemukan di PAUD umumnya kurang memiliki nilai pemanfaatan bahan yang ada disekitar sekolah. Sekolah cenderung mengesampingkan ketrampilan pendidik dalam pengembangan media pembelajaran dengan cara membeli media secara langsung yang beredar di pasaran (Jazariyah, 2019). 
Penggunaan media tidak mesti harus yang mahal, dan lazim dipakai guru pada umumnya, tetapi harus memperhitungkan juga nilai ekonomis dan nilai praktis serta mudah didapatkan. Kadang-kadang media yang ada sekitar siswa dapat digunakan secara baik oleh guru. Hal itu dapat dibuktikan hasil penelitiannya Hafidz Manaf pada tahun 2019 hasil penelitiannya menunjukkan pembelajaran melalui media celemek ilmu yang apabila dilakukan secara sistematis dan berkesinambungan maka akan berdampak baik dalam meningkatkan pengembangan aritmatika anak di lembaga PAUD (Muhajir, 2019).

Media pembelajaran snagat penting dikembangkan oleh para guru terutama di lembaha PAUD. Sejalan dengan hal itu, maka media pengajaran digunakan dalam rangka upaya peningkatan atau memperbaiki mutu kegiatan belajar-mengajar yang akan dillakukan di sekolah (Zaini \& Dewi, 2017)

\section{Pelaksanaan Pembelajaran Berbasis Fortofolio}

Setelah dilaksanakan pretest, kemudian pada melakukan langkah-langkah perkuliahan mengenai strategi pengembangan media pembelajaran PAUD dengan model belajar berbasis fortofolio.

Mengacu pada pendapatnya Budimansyah dalam Purba (Purba, 2006) bahwa pembelajaran berbasis portofolio, yaitu: 1). identifikasi masalah, 2). memilih masalah untuk kajian kelas, 3). mengumpulkan informasi tentang masalah yang akan disajikan oleh kelas dan 4). mengembangkan portofolio kelas.

Berdasarkan pendapat di atas, maka langkah-langkah Pembelajaran Berbasis Portofolio adalah sebagai berikut:

\section{a. Mengidentifikasi masalah}

Pada tahap ini dosen bersama mahasiswa mendiskusikan tujuan, mencari masalah, apa saja yang mahasiswa ketahui, tentang masalah-masalah mengenai membaca dan mengenal huruf serta strategi yang akan digunakan. Setiap mahasiswa diberikan lembaran tugas yang berisi tentang kompetensi inti dan kompetensi dasar serta STPPA dan tujuan pembelajaran membaca dan mengenal huruf bagi siswa PAUD untuk kelas A dan kelas B. Di dalamnya disediakan kolom-kolom yang harus diisi oleh mahasiswa yang berhubungan dengan strategi 
pengembangan media pembelajaran yang sesuai dengan materi membaca dan mengenali huruf tersebut

\section{b. Memilih masalah untuk kajian kelas}

Berdasarkan kegiatan pertama di atas, kemudian mahasiswa diminta untuk mengidentifikasi berbagai permasalahan yang muncul yang berhubungan dengan strategi pengembangan media pembelajaran di PAUD serta mencermati beberapa permasalahan yang paling sering muncul di kelas yang dimaksud yang paling muncul di kelas adalah mengenai efektivitas media pembelajaran yang biasa digunakan oleh guru khususnya dalam masalah pembelajaran membaca dan mengenal huruf. Pada tahap ini para mahasiswa memilih beberapa masalah menjadi lebih spesifik agar dapat dikaji secara bersama-sama di kelas. Masing-masing mahasiswa memberikan atau mengajukan permasalahan yang berbeda terkait dengan pengembangan media pembelajaran membaca dan mengenal huruf di kelas.

c. Mengumpulkan informasi yang terkait dengan masalah yang dikaji

Setelah memilih dan mengidentifikasi masalah yang lebih spesifik terkait dengan model pengembangan media pembelajaran di PAUD, selanjutnya mahasiswa secara berpasangan mengidentifikasi beberapa solusi alternatif serta menjelaskan an kemungkinankemungkinan atau semacam dugaan yang dianggap dapat memperbaiki atau membantu dalam pengembangan dan media pembelajaran untuk pelajaran membaca dan mengenal huruf yang bersifat edukatif, praktis, ekonomis dan kontekstual.

\section{d. Menyusun Fortofolio Kelas}

Kelas dibagi dalam 7 kelompok dan setiap kelompok akan bertanggung jawab untuk membuat satu bagian portofolio. Berdasarkan hasil analisis permasalahan yang dilakukan secara individu di awal pembelajaran, kemudian permasalahan itu dikumpulkan dalam sebuah kelompok yang terdiri dari 4 atau 5 mahasiswa berkelompok. Pada bagian ini dosen pembimbing mahasiswa untuk mengerjakan portofolio. Untuk mempermudah pengerjaan portofolio, dosen menyediakan sejenis template untuk mengisi bagian bagian yang sengaja dikosongkan kan agar diselesaikan oleh mahasiswa sesuai dengan permasalahan masingmasing, tema yang berbeda-beda, dan masalah masing-masing yang berbeda-beda. Pada 
kegiatan ini dosen berkeliling untuk memfasilitasi kegiatan diskusi kelompok dan memberikan beberapa pengarahan, penjelasan untuk membantu kegiatan diskusi mahasiswa.

Pada bagian ini mahasiswa diminta untuk mengkaji strategi pengembangan media pembelajaran berdasarkan aspek Kesesuaian Media Pembelajaran dengan Tujuan Pembelajaran, Unsur edukasi dalam Media Pembelajaran, Langkah-langkah (petunjuk) dalam penggunaan media pembelajaran dan nilai praktis, ekonomis dan kontekstual dalam media yang diajukan atau akan digunakan.

\section{e. Menyajikan fortofolio/dengar pendapat}

Masing-masing kelompok melalui perwakilannya menjelaskan di depan kelas mengenai hasil diskusi nya seperti menjelaskan alternatif media yang diajukan, nilai edukatif kepraktisan serta tingkat kontekstual antara media alternatif dengan tema pembelajaran di PAUD. Dalam kegiatan ini mahasiswa dipersilakan untuk berdiskusi baik dengan teman kelompoknya maupun dengan mahasiswa yang lain baik dalam bentuk tanya jawab maupun adu gagasan.

Pemilihan model pembelajaran berbasis portofolio dalam perkuliahan pengembangan media pembelajaran, karena berdasarkan kajian peneliti pembelajaran berbasis fortofolio dapat meningkatkan motivasi belajar mahasiswa. Hal ini didukung oleh hasil penelitiannya Ali Sadikin pada tahun 2016. Dalam penelitian tersebut disebutkan bahwa dengan model portofolio motivasi mahasiswa untuk belajar dan berkarya menjadi lebih baik dari setiap perubahan siklusnya dengan rata-rata skor akhir mencapai 89,50 dari 100 skor maksimal. (Sadikin et al., 2016).

\section{Pos Test Pemahaman Mahasiswa dalam Strategi Pengembangan Media Pembelajaran}

Setelah kegiatan perkulaian selesai, kemudian dilaksanakan kegiatan postest. Berdasarkan analisis data posttest, diperoleh nilai pemahaman mahasiswa dalam pengembangan media pembelajaran penulis rangkum pada tabel berikut ini. 
AWLADY: Jurnal Pendidikan Anak

Vol. 6, No. 1, Maret 2020

Homepage: www.syekhnurjati.ac.id/jurnal/index.php/awlady

Email : pgrasyekhnurjati@gmail.com

P-ISSN: 2541-4658

E-ISSN: 2528-7427

Tabel 2

Nilai Postest Mahasiswa

\begin{tabular}{|c|c|c|c|c|c|}
\hline \multirow{2}{*}{$\begin{array}{c}\text { Kode } \\
\text { Mahasiswa }\end{array}$} & \multicolumn{4}{|c|}{ Indikator Penilaian } & \multirow{2}{*}{ NILAI AKHIR } \\
\hline & 1 & 2 & 3 & 4 & \\
\hline S 1 & 20 & 25 & 20 & 20 & 85 \\
\hline S 2 & 25 & 20 & 20 & 15 & 80 \\
\hline S 3 & 20 & 20 & 20 & 15 & 75 \\
\hline S 4 & 15 & 25 & 25 & 20 & 85 \\
\hline S 5 & 25 & 20 & 25 & 20 & 90 \\
\hline S 6 & 15 & 20 & 25 & 20 & 80 \\
\hline S 7 & 20 & 25 & 20 & 15 & 80 \\
\hline S 8 & 25 & 25 & 20 & 15 & 85 \\
\hline S 9 & 20 & 25 & 20 & 20 & 85 \\
\hline S 10 & 20 & 20 & 20 & 20 & 80 \\
\hline S 11 & 25 & 20 & 20 & 15 & 80 \\
\hline S 12 & 20 & 20 & 25 & 15 & 80 \\
\hline $\mathrm{S} 13$ & 20 & 20 & 25 & 20 & 85 \\
\hline S 14 & 20 & 25 & 25 & 10 & 80 \\
\hline S 15 & 25 & 25 & 15 & 20 & 85 \\
\hline S 16 & 20 & 25 & 15 & 20 & 80 \\
\hline S 17 & 25 & 25 & 25 & 20 & 95 \\
\hline S 18 & 25 & 20 & 20 & 25 & 90 \\
\hline S 19 & 20 & 25 & 20 & 20 & 85 \\
\hline S 20 & 25 & 20 & 20 & 15 & 80 \\
\hline S 21 & 25 & 25 & 20 & 25 & 95 \\
\hline S 22 & 20 & 25 & 25 & 15 & 85 \\
\hline S 23 & 20 & 25 & 20 & 15 & 80 \\
\hline S 24 & 25 & 20 & 25 & 15 & 85 \\
\hline S 25 & 25 & 25 & 20 & 15 & 85 \\
\hline S 26 & 25 & 25 & 25 & 20 & 95 \\
\hline S 27 & 20 & 25 & 20 & 20 & 85 \\
\hline S 28 & 25 & 25 & 15 & 20 & 85 \\
\hline S 29 & 25 & 20 & 20 & 20 & 85 \\
\hline S 30 & 20 & 20 & 25 & 20 & 85 \\
\hline \multicolumn{5}{|c|}{ RATA-RATA } & 84,33 \\
\hline
\end{tabular}


Indikator :

1 = Kesesuaian Media Pembelajaran dengan Tujuan Pembelajaran

2 = Unsur edukasi dalam Media Pembelajaran

3 = Langkah-langkah (petunjuk) dalam penggunaan media pembelajaran

4 = Media Pembelajaran Bernilai praktis, ekonomis dan kontekstual

Berdasarkan deskripsi di atas, dapat disimpulkan bahwa setelah penerapan model pembelajaran berbasis portofolio, kemampuan dan pemahaman mahasiswa dalam menggunakan dan mengembangkan media pembelajaran di PAUD menjadi meningkat signifikan terbukti dengan skor rata-rata dari 54 menjadi 84,33 dari skor maksimal 100 . Namun dari skor yang diperoleh berdasarkan empat indikator penilaian, dilakukan terhadap mahasiswa dapat diketahui bahwa kemampuan mahasiswa yang paling rendah adalah dalam membuat media pembelajaran yang bernilai praktis, ekonomis dan kontekstual. Oleh karena itu, maka tindak lanjutnya adalah harus lebih mengembangkan pembelajaran pada aspek penenakan kontekstualisasi media pembelajaran PAUD yang lebih efektif, praktis dan bernilai ekonomis.

Berdasarka data di atas, dapat diketahui bahwasannya perkuliahan berbasis portofolio dapat meningkatkan kemampuan dan pemahaman mahasiswa dalam mengembangkan media pembelaran untuk PAUD yang lebih baik. Baik itu dari sisi edukasinya, nilai ekonomisnya, kepraktisan cara menggunakan serta kontekstualisasi media dengan tema pelajaran yang disampaikan pada siswa PAUD.

\section{Uji Hipotesis}

Untuk mengetahui keberhasilan proses pembelajaran mengenai pemahaman mahasiswa dalam strategi pengembangan media pembelajaran, maka dilakukan analisis data kuantitatif model eksperimen melalui perbandingan hasil pretes dan postes. Adapun langkah-langkahnya adalah sebagai berikut:

\section{a. Mencari nilai maksimum, minimum, dan nilai rata-rata Pretest dan Postest}

Dengan menggunakan SPSS, maka nilai minimun, maksimum dan nilai rata-rata dari pre-test dan postes dapat dirangkum seperti pada tabel di bawah ini. 
Tabel 3

Nilai Minimum, Maksimum, rata-rata dari Pretest dan Postes

\begin{tabular}{l|r|r|r|r|r|r}
\hline & $\mathrm{N}$ & \multicolumn{1}{|c|}{ Minimum } & Maximum & Mean & Std. Deviation & Variance \\
\hline Pretest & 30 & 35,00 & 70,00 & 54,0000 & 9,68468 & 93,793 \\
Postest & 30 & 75,00 & 95,00 & 84,3333 & 4,86602 & 23,678 \\
Valid N (listwise) & 30 & & & & & \\
\hline
\end{tabular}

Berdasarkan tabel di atas, dapat diketahui bahwa nilai paling kecil dari pretest adalah 35 dan nilai terkecil postes adalah 75 . Nilai terbesar pretest adalah 70 sedangkan postes adalah 95. Rata-rata nilai pretest adalah 54 sedangkan postest adalah 84,33.

\section{b. Menguji Normalitas}

Menguji normalitas data dengan menggunakan Shapiro-Wlik dengan taraf signifikan $\alpha$ yang dipilih (biasanya $\alpha=0,05$ ). Dengan menggunakan perhitungan SPSS dapat diperoleh normalitas sebagai berikut:

Tabel 4

Uji Normalitas Pretest dan Postest

\begin{tabular}{|c|c|c|c|c|c|c|}
\hline & \multicolumn{3}{|c|}{ Kolmogorov-Smirnov ${ }^{a}$} & \multicolumn{3}{|c|}{ Shapiro-Wilk } \\
\hline & Statistic & df & Sig. & Statistic & df & Sig. \\
\hline Sebelum &, 141 & 30 & ,131 & ,955 & 30 & ,235 \\
\hline Sesudah & ,279 & 30 &, 000 & ,846 & 30 & ,001 \\
\hline
\end{tabular}

a. Lilliefors Significance Correction

Dari tabel di atas, dapat diketahui bahwa nilai Sig. untuk pemahaman mahasiswa sebelum pembelajaran 0,235 Sedangkan nilai sig untuk pemahaman mahasiswa setelah pembelajaran adalah 0,001 . Dengan rumusan hipotesis $h_{0}=$ data berdistribusi normal, jika nilai sig $\geq \alpha$, dan $h_{1}=$ data tidak berdistribusi normal jika nilai sig $<=\alpha$, maka berarti data pemahaman mahasiswa sebelum pembelajaran adalah berdistribusi tidak normal sedangkan pemahaman mahasiswa tentang strategi pengembangan media pembelajaran setelah perkuliahan adalah berdistribusi normal karena nilai sig lebih kecil dari nilai $\alpha(0,05)$. 
AWLADY: Jurnal Pendidikan Anak

Vol. 6, No. 1, Maret 2020

Homepage: www.syekhnurjati.ac.id/jurnal/index.php/awlady

Email : pgrasyekhnurjati@gmail.com

P-ISSN: 2541-4658

E-ISSN: 2528-7427

\section{c. Dampak Pembelajaran Berbasis Fortofolio Terhadap Pemahaman Mahasiswa}

Untuk melihat seberapa besar dampak dari pembelajaran fortofolio terhadap pemahaman mahasiswa dalam pengembangan media pembelajaran, maka perlu dilakukan uji $t$ paired dengan SPSS. Adapun hasilnya adalah sebagai berikut:

Tabel 4

Paired Samples Statistics

\begin{tabular}{|rl|r|r|r|r|}
\hline & & Mean & N & \multicolumn{1}{c|}{ Std. Deviation } & \multicolumn{1}{c|}{ Std. Error Mean } \\
\hline \multirow{2}{*}{ Pair 1 } & Sebelum & 54,00 & 30 & 9,685 & 1,768 \\
& Sesudah & 84,33 & 30 & 4,866 &, 888 \\
\hline
\end{tabular}

Pada tabel di atas, dapat diketahui bahwa hasil statistik deskriptif dari pretest dan postes. Untuk nilai Pretest diperoleh rata-rata hasil belajar atau Mean sebesar 54,00. Sedangkan untuk nilai Post Test diperolah nilai rata-rata hasil belajar sebesar 84,33. Jumlah responden yang digunakan sebagai sampel penelitian adalah sebanyak 30 orang mahasiswa.

Untuk nilai Std. Deviation (standar deviasi) pada Pre Test sebesar 9,68 dan Post Test sebesar 4,86. Terakhir adalah nilai Std. Error Mean untuk Pre Test sebesar 1,768 dan untuk Post Test sebesar 0,888. Karena nilai rata-rata pada Pretest lebih besar dari Posttest, maka itu artinya secara deskriptif ada perbedaan rata-rata hasil belajar antara Pre Test dengan hasil Postest. Selanjutnya untuk membuktikan apakah perbedaan tersebut benar-benar nyata (signifikan) atau tidak, maka kita perlu menafsirkan hasil uji paired sample t test yang terdapat pada tabel output "Paired Samples Test" dengan tabel berikut ini

Tabel 5

Paired Samples Correlations

\begin{tabular}{|l|r|r|r|}
\hline & N & Correlation & \multicolumn{1}{|c|}{ Sig. } \\
\hline Pair $1 \quad$ Sebelum \& Sesudah & 30 &, 370 &, 044 \\
\hline
\end{tabular}

Pada tabel di atas menunjukkan hasil uji korelasi atau hubungan antara kedua data atau hubungan variabel Pretest dengan variabel Posttest diketahui nilai koefisien korelasi (Correlation) sebesar 0,370 dengan nilai signifikansi (Sig.) sebesar 0,44. Karena nilai Sig. 0,44 lebih kecil daripada probabilitas $(=0,05)$, maka dapat dikatakan bahwa ada hubungan 
AWLADY: Jurnal Pendidikan Anak

Vol. 6, No. 1, Maret 2020

Homepage: www.syekhnurjati.ac.id/jurnal/index.php/awlady

Email : pgrasyekhnurjati@gmail.com

P-ISSN: 2541-4658

E-ISSN: 2528-7427

antara variabel Pretest dengan variabel Posttest pemahaman mahasiswa dalam strategi pengembangan media pembelajaran.

Untuk menjawab ada atau tidaknya pengaruh antara penerapan pembelajaran berbasis fortofolio terhadap pemahaman mahasiswa dalam strategi pengembangan media pembelajaran dapat diketahui melalui tabel berikut ini.

Tabel 6

Paired Samples Test

\begin{tabular}{|c|c|c|c|c|c|c|c|c|c|}
\hline & & \multicolumn{5}{|c|}{ Paired Differences } & \multirow[t]{3}{*}{$\mathrm{t}$} & \multirow[t]{3}{*}{$d f$} & \multirow{3}{*}{$\begin{array}{l}\text { Sig. (2- } \\
\text { tailed) }\end{array}$} \\
\hline & & \multirow[t]{2}{*}{ Mean } & \multirow[t]{2}{*}{$\begin{array}{c}\text { Std. } \\
\text { Deviation }\end{array}$} & \multirow[t]{2}{*}{$\begin{array}{l}\text { Std. Error } \\
\text { Mean }\end{array}$} & \multicolumn{2}{|c|}{$\begin{array}{c}95 \% \text { Confidence } \\
\text { Interval of the } \\
\text { Difference }\end{array}$} & & & \\
\hline & & & & & Lower & Upper & & & \\
\hline Pair 1 & $\begin{array}{l}\text { Sebelu } \\
\text { m - } \\
\text { Sesud } \\
\text { ah }\end{array}$ & $-30,333$ & 9,091 & 1,660 & $-33,728$ & $-26,939$ & $-18,276$ & 29 & ,000 \\
\hline
\end{tabular}

Berdasarkan tabel "Paired Samples Test" di atas, diketahui nilai Sig. (2-tailed) adalah sebesar 0,000 dan lebih kecil dari nilai alfa yaitu 0,05, maka ini artinya $\mathrm{H} 0$ ditolak dan $\mathrm{Ha}$ diterima. Sehingga dapat disimpulkan bahwa ada perbedaan rata-rata antara hasil belajar Pretest dengan Posttest. Dengan kata lain, ada pengaruh penggunaan pembelajaran berbasis fortofolio terhadap pemahaman mahasiswa dalam mengembangkan media pembelajaran.

Dari tabel "Paired Samples Test" di atas juga dapat diketahui bahwa nilai "Mean Paired Differences" adalah sebesar -30,333. Nilai ini menunjukkan selisih antara rata-rata hasil belajar Pretest dengan rata-rata hasil belajar Posttest atau 84,33-54,00= -30,333 dan selisih perbedaan tersebut antara -33,279 sampai dengan -26,939 (95\% Confidence Interval of the Difference Lower dan Upper).

Berdasarkan pada analisis data di atas, maka dapat diketahui bahwa perkuliahan yang dilaksanakan dengan berbasis fortofolio dapat mengembangkan pemahaman dan kemampuan mahasiswa dalam mengembangkan media pembelajaran pada siswa PAUD. 
Perkuliahan berbasis portofolio merupakan hasil kerja mahasiswa. Hasil kerja mahasiswa ini berupa karya yang dikumpulkan selama proses perkuliahan dalam periode waktu tertentu. Karya tersebut diseleksi dan disusun menjadi satu portofolio.

Perkuliahan dengan model portofolio merupakan sebuah inovasi dalam pembelajaran sebagai wujud nyata dari pembelajaran kontekstual. Pembelajaran portofolio mengandalkan partisipasi mahasiswa untuk turun ke lapangan untuk menghubungkan antara teori dengan praktik nyata di lapangan di bawah bimbingan dosen atau guru guna memperoleh sebuah pengalaman langsung yang hasilnya harus disajikan di kelas oleh masing-masing kelompok dengan masalah yang dipilihnya (Winataputra, 2008:78).

Mengacu pada pendapat tersebut, maka hal ini terbukti dengan hasil penilaian kemampuan dan pemahaman mahasiswa tentang media pembelajaran PAUD baik pada penilaian pretest maupun posttest. Kedua hasil tersebut menunjukka indikator yang paling rendah pada kemampuan mahasiswa adalah pada aspek kontekstualisasi media pembelajaran yang tema atau kegiatan pelajaran yang dilakukan di sekolah. Oleh karena itu, penerapan perkuliahan berbasis portofolio merupakan salah satu cara yang efektif digunakan dalam perkuliahan agar meningkatkan pemahaman dan pengetahuan mahasiswa tentang penggunaan media pembelajaran pada siswa PAUD.

Berdasarkan hasil skor rata-rata pretest mahasiswa hanya memperoleh angka 54 sedangkan setelah proses pembelajaran meningkat menjadi 84,33. Angka tersebut menunjukkan terjadi peningkatan kemampuan rata-rata sebesar 56,17 persen. Sedangkan dengan perhitungan statistik uji t menunjukkan ada perbedaan rata-rata antara kemampuan dan pemahaman dari Pretest dengan Posttest. Dengan kata lain, adanya pengaruh penggunaan pembelajaran berbasis fortofolio terhadap pemahaman mahasiswa dalam mengembangkan media pembelajaran.

Paradigma dalam pembelajaran portofolio ialah pembelajaran yang menghendaki inovasi yang terpadu dan berkesinambungan. Salah satu wujudnya adalah inovasi yang dilakukan oleh guru atau dosen dalam kegiatan pembelajaran di kelas dan usaha atau kreatifitas dosen dalam yaitu dengan mengumpulkan mengumpulkan informasi mengenai tingkat pemahaman mahasiswa sebuah karya pengembangan media pembelajaran di PAUD. 
Keberhasilan portofolio ini ternyata mendukung juga hasil penelitian pada bidang lain yang hampir sama yaitu membutuhkan karya dan inovasi. Seperti halnya hasil penelitian yang dilakukan Rohani pada tahun 2015 yang pada hasil penelitian yang dilakukan, diperoleh hasil belajar siswa yang menggunakan model pembelajaran berbasis portofolio lebih baik apabila dibandingkan dengan prestasi belajar siswa yang belajar dengan menggunakan pembelajaran konvensional. (Hamid, Abdul, 2008).

\section{SIMPULAN}

Berdasarkan pembahasan di atas, maka dapat ditarik beberapa kesimpulanbahwa pemahaman mahasiswa dalam strategi pengembangan media pembelajaran di PAUD sebelum pelaksanaan perkuliahan dapat dikategorikan pada pemahaman yang rendah. Hal ini diketahui dengan rata-rata akhir skor pemahaman siswa adalah 54,00. Setelah proses perkuliahan dengan model perkuliahan berbasis fortofolio, pemahaman dan kemampuan mahasiswa menjadi meningkat dari 54,00. Menjadi adalah 84, 33. Angka tersebut menunjukkan pemahaman siswa meningkat secara signifikan. Hasil uji hipotesis uji $\mathrm{t}$ independent $t$ test menunjukkan ada pengaruh penggunaan pembelajaran berbasis fortofolio terhadap pemahaman mahasiswa dalam mengembangkan media pembelajaran. Berdasarkan 4 indikator penilaian, diketahui bahwa pemahaman yang paling rendah adalah pada indikator nomor 4 yaitu nilai kepraktisan, ekonomis dan nilai kontekstual pada media yang akan digunakan dalam pembelajaran, sementara 3 indikator lainnya cenderung memiliki skor yang hampir sama.

\section{DAFTAR PUSTAKA}

BSNP. (2017). Peraturan Menteri Pendidikan Nasional Nomor 41 tahun 2007 tentang Standar Proses untuk satuan pendidikan Dasar dan Menengah. In Jakarta, Depdiknas.

Depdiknas. (2004). Kurikulum 2004 Kerangka Dasar (Taman Kanak-Kanak dan Raudlatul Athfal (TK \& RA)). Depdiknas.

Hamid, Abdul, R. (2008). Pengaruh Model Pembelajaran Berbasis Portofolio Dan Kemampuan Awal Terhadap Hasil Belajar Pendidikan Kewarganegaraan. Jurnal Teknologi Pendidikan (JTP), 8(1).

Jazariyah, J. (2019). Papan Huruf Flanel: Media Pembelajaran Keaksaran Awal Untuk Anak Usia Dini. AWLADY: Jurnal Pendidikan Anak, 5(2), 1-15. 
Muhajir, H. M. (2019). Efektivitas Media Celemek Ilmu Terhadap Pengembangan Aritmatika Anak Umur 5-6 Tahun Di Taman Kanak-Kanak Kota Palopo. AWLADY: Jurnal Pendidikan Anak, 5(2), 146-161.

Nurapriani, R., Yanuarsari, R., Ruswandi, A., Muchtar, H., \& Hakim, L. (2018). Indonesian Vocabulary Learning for Early Childhood Using Paper Puppet Media. Proceedings of the 1st International Conference on Science and Technology for an Internet of Things.

Piran, Wiroatmodjo, S. (2002). Media Pembelajaran. LAN RI.

Purba, A. (2006). Pengantar Ilmu Komunikasi. Pustaka Bangsa Press: Medan.

Sadikin, A., Aina, M., \& Hakim, N. (2016). Penerapan Ssesmen Berbasis Portofolio dan Jurnal Belajar Untuk Meningkatkan Kemampuan Metakognitif dan Motivasi Belajar Mahasiswa pada Mata Kkuliah Perencanaan Pengajaran Biologi. BIODIK, 2(2), 50-61.

Sadiman, A. S. (1996). Media Pendidikan: Pengertian, Pengembangan, dan. Pemanfaatannaya. Jakarta: Raja Grafindo Persada.

Shochib, M. (1998). Pola Asuh Orang Tua dalam Membantu Disiplin Diri. Jakarta: PT Rieneka Cipta.

Sugiyono, D. (2011). Metode Penelitian Kuantitatif Kualitatif dan R\&D. CV Alfabeta.

Suharsimi, A. (2006). Prosedur Penelitian Suatu Pendekatan Praktik. Rhineka Cipta.

Trianto, T. (2010). Model Pembelajaran Terpadu. Bumi Aksara.

Zaini, H., \& Dewi, K. (2017). Pentingnya Media Pembelajaran untuk Anak Usia Dini. Raudhatul Athfal: Jurnal Pendidikan Islam Anak Usia Dini, 1(1), 81-96. 